\title{
Variation in Anatomical Characteristics in Leaves of Pecan Seedstocks from Mexico and the United States
}

\author{
Madhulika Sagaram and Leonardo Lombardini ${ }^{1}$ \\ Department of Horticultural Sciences, Texas A\&M University, College Station, TX 77843 \\ L.J. Grauke \\ Pecan Genetics and Breeding Program, Agricultural Research Service, U.S. Department of \\ Agriculture, 10200 FM50, Somerville, TX 77879
}

\begin{abstract}
Additional Index words. carbon isotopic discrimination, Carya illinoinensis, ecogeographical traits, stomatal density, stomatal index

Abstract. Leaf anatomical traits of Mexican and U.S. pecan [Carya illinoinensis (Wangenh.) K. Koch] seedstocks grown in a single location were studied to determine patterns of ecogeographic variation within the natural range. Stomatal density was uniform among open-pollinated seedlings of a common maternal parent with twofold differences in stomatal density separating some seedstocks. There was an inverse relationship between stomatal density and epidermal cell density. Stomatal density and stomatal index of Mexican seedstocks were related to longitude and annual precipitation of origin. Stomatal density increased along the longitudinal gradient toward the east coast of Mexico; seedstocks originating from areas on the east coast of Mexico had greater stomatal density than seedstocks originating from the drier areas on the west coast. Stomatal density and stomatal index did not follow a pattern along latitude or longitude in the U.S. seedstocks. Although isotopic carbon $\left({ }^{13} \mathrm{C}\right)$ discrimination did not vary greatly in Mexican seedstocks, the reduction in stomatal density in pecan trees from areas with reduced annual precipitation suggest the presence of an anatomical feature to reduce water losses.
\end{abstract}

Pecan is distributed over a broad geographic area, encompassing tremendous climatic variation. The native range of pecan extends $\approx 26^{\circ}$ in latitude from northern Iowa (lat. $42^{\circ} 20^{\prime}$ $\mathrm{N}$ ) to Oaxaca in Mexico (lat. $16^{\circ} 30^{\prime} \mathrm{N}$ ), and $\approx 20^{\circ}$ in longitude, because native trees are found as far east as Butler County, $\mathrm{OH}$ (long. $84^{\circ} 35^{\prime} \mathrm{W}$ ) and as far west as the Valle de Allende in Chihuahua, Mexico (long. $105^{\circ} 24^{\prime}$ W) (Thompson and Grauke, 1991). Pecan seedlings grown from seeds collected from native populations across the range have been distinguished on the basis of phenology (Wood et al., 1998). Seedlings arising from southern sources begin growth earlier in the spring and maintain growth later into the fall than those from northern sources, in conformity to differences in the lengths of growing season at their origins (Wood et al., 1998).

Studies conducted on ponderosa pine (Pinus ponderosa Dougl. ex Laws) reported intraspecific variation for anatomical and physiological traits such as stomatal density [SD (stomata/ $\left.\mathrm{mm}^{2}\right)$ ] and gas exchange (Cregg, 1993, 1994). According to Jones (1998), features of leaf surface anatomy are a complex of traits defined by stomatal characteristics (SD, frequency, and position) and epidermal characteristics (density, shape, and size of epidermal cells). Studies conducted on several species of grasses reported that SD did not have a profound effect on

Received for publication 16 Dec. 2010. Accepted for publication 5 Feb. 2011. This project was funded in part by a Specific Cooperative Agreement (SCA 58-6202-6-095) between USDA-ARS Southern Plains Area and the Texas Agricultural Experiment Station.

Mention of a trademark, proprietary product, or vendor does not constitute a guarantee or warranty of the product by the authors, the Texas A\&M University, the Texas Agricultural Experiment Station, or sponsors of the research and does not imply its approval to the exclusion of other products or vendors that also may be suitable.

We thank Dr. Brian Shaw, Department of Plant Pathology and Microbiology, Texas A\&M University, for allowing the use of the microscope equipment.

${ }^{1}$ Corresponding author. E-mail: 1-lombardini@tamu.edu. photosynthesis (Jarvis and Davies, 1998; Jones, 1998). In addition, a weak correlation between SD and plant productivity was reported in wheat [Triticum aestivum L. (Bhagwat and Bhatia, 1993)], rice [Oryza sativa L. (Yamashita et al., 1995)], perennial ryegrass [Lolium perenne L. (Wilson, 1971)], and azalea [Rhododendron simsii Planch. (Heursel et al., 1987)]. However, SD has been related to tolerance to abiotic stress conditions such as drought (Jarvis and Davies, 1998; Van Rensburg et al., 1999) and temperature extremes (Kleinhenz et al., 1995; Nayeem, 1989). In Arabidopsis thaliana (L.) Heynh, SD has been linked to mechanisms of instantaneous water use efficiency (WUE), indicating the importance of SD for plant survival in drought conditions (Masle et al., 2005). In a study conducted on five seedstocks of Eucalyptus microtheca F. Muell. seedlings grown under different water regimes, differences were observed for WUE (Li, 2000). The study indicated that WUE may be a valuable tool for selecting genotypes with improved drought adaptation and biomass under different environmental conditions ( $\mathrm{Li}, 2000)$. Hence, there may be a possibility of such a selection for pecan trees.

Anatomical studies have also been conducted on leaf characteristics of species of the Juglandaceae. Leaf surface features of pecan were studied by Nagel (1914) and Parmentier (1911) followed by a detailed study of the leaf surface features of juvenile and adult pecan leaves (Grauke et al., 1987). Although some studies focused on leaf surface characteristics (Grauke et al., 1987; Hardin and Stone, 1984), Nemati and Roberts (1968) studied the SD of various pecan cultivars and reported that differences existed. A more recent study showed that $\mathrm{SD}$, epidermal cell density [ED (epidermal cells $/ \mathrm{mm}^{2}$ )], and stomatal index $\{\mathrm{SI}=[\mathrm{SD} /(\mathrm{SD}+\mathrm{ED})] \times 100\}$ did not change in pecan trees of the same cultivar grown at different ecogeographical locations (Sagaram et al., 2007). This indicates that the stability of certain leaf anatomical characteristics such as SD and ED may be linked to the long-term climatic 
conditions of the location where the species (or population) developed rather than their current planting location.

The objectives of the present study were to determine whether WUE and anatomical characteristics vary among 19 seedstocks of $C$. illinoinensis in its natural distribution and to analyze the relationships between anatomical features and environmental parameters of the seedstocks' site of origin (such as elevation and precipitation) along geographical gradients. Such information is conducive to enhanced selection of suitable genotypes of this species for different environmental conditions.

\section{Materials and Methods}

Plant material. The U.S. Department of AgricultureAgricultural Research Service (USDA-ARS) National Collection of Genetic Resources (NCGR) for Pecans and Hickories maintains several orchards in Burleson County, TX (lat. 30 ${ }^{\circ} 31^{\prime}$ $\mathrm{N}$, long. $96^{\circ} 25^{\prime} \mathrm{W}$ ). Trees in the present test were a part of the College Station Mexican (CSM) Provenance orchard, located near College Station, TX (lat. $30^{\circ} 37^{\prime} \mathrm{N}$, long. $96^{\circ} 30^{\prime} \mathrm{W}$, elevation $67 \mathrm{~m}$ ), and comprised of seedling trees grown from seed of diverse origin. Much of the seed was obtained from entries of native pecans submitted by their owners to the Third Mexican National Nut Conference held at Piedras Negras, Coahuila, in Nov. 1994. To represent more northern populations for comparison, seed was also collected from pecan cultivars known to have originated throughout the United States but being grown as grafted trees in orchards of the USDA-ARS-NCGR in Brownwood, TX. All seed was openpollinated with the seed from Mexican natives being pollenized by other pecan trees growing at the CSM orchard. Seed from grafted pecan cultivars in the NCGR could have been pollenized by any of the diverse accessions in the USDA-ARS orchards in Brownwood. Seedlings were planted in 1997 with
$4.5 \mathrm{~m}$ between rows and $5.5 \mathrm{~m}$ between trees in the row. Total orchard size is 3.52 ha. The CSM orchard includes 1400 seedlings grown from the previously described seeds, organized in eight blocks of 175 seedlings each, in an unbalanced design with \pm 1 seedling from each seedstock in each block.

Nineteen seedstocks from 14 Mexican and five U.S. locations were selected for inclusion in the current research (Table 1; Fig. 1). Three seedlings of those seedstocks were sampled from three blocks, except for seedstocks $8,9,10,11,13$, and 18 for which only two seedlings were available. Soil type varies among the three blocks from Weswood silty clay loam (Block 1) to Ships clay (Block 3). Block 2 transitioned between Weswood soil and Ships soil. Weswood soils are loamy, well drained, very deep, moderately permeable, nearly level or very gently sloping soils with $0 \%$ to $3 \%$ slope (Jurena, 2005). Ships series are characterized by very deep, moderately well drained, very slowly permeable soils that formed in clayey alluvial sediments and nearly leveled or very gently sloping (Jurena, 2005). At the time of the present investigation, trunk diameter at breast height $(130 \mathrm{~cm})$ ranged between 6 and $24 \mathrm{~cm}$, depending on the seedstock.

SAMPLE PREPARATION AND MICROSCOPY ANALYSIS. Leaves were collected from the north and south sides of the trees. Pecan leaves are hypostomatic with anomocytic stomata (Grauke, 1982); consequently, only the leaf abaxial sides were investigated. To determine the density of stomata and epidermal cells, the abaxial side of the distal pair of leaflets was coated with clear nail enamel (Fisher, 1985). After the enamel was allowed to dry for 10 to $15 \mathrm{~min}$, the cast was stripped using clear tape and placed on microscope slides as described in Sagaram et al. (2007). Samples were collected from all trees on the same day and handled uniformly. Five casts were obtained from different leaves on each tree in the test. Number of cells present in each measurement area was counted using a microscope guide as a reference as previously described (Sagaram

Table 1. Latitude, longitude, elevation, and mean annual precipitation at sites of origin for open-pollinated pecan seeds from the United States (seedstocks 1-4 and 6) and Mexico (seedstocks 5 and 7-19) used in the study. ${ }^{\mathrm{r}}$

\begin{tabular}{|c|c|c|c|c|c|c|c|c|}
\hline \multirow{2}{*}{$\begin{array}{l}\text { Seedstock } \\
\text { no. }\end{array}$} & \multirow[b]{2}{*}{ Identification } & \multicolumn{5}{|c|}{ Origin } & \multirow{2}{*}{$\begin{array}{c}\text { Elevation } \\
\text { (m) }\end{array}$} & \multirow{2}{*}{$\begin{array}{c}\text { Annual } \\
\text { precipitation } \\
(\mathrm{mm})\end{array}$} \\
\hline & & County & State & Country & Latitude & Longitude & & \\
\hline 1 & Burkett & Callahan & Texas & U.S. & $-32^{\circ} 22^{\prime}$ & $99^{\circ} 10^{\prime}$ & 549 & 648 \\
\hline 3 & Major & Henderson & Kentucky & U.S. & $-37^{\circ} 54^{\prime}$ & $87^{\circ} 29^{\prime}$ & 131 & 1150 \\
\hline 4 & Dooley & Okmulgee & Oklahoma & U.S. & $-35^{\circ} 37^{\prime}$ & $96^{\circ} 01^{\prime}$ & 192 & 1104 \\
\hline 5 & Frutoso & Parras & Coahuila & Mexico & $-25^{\circ} 25^{\prime}$ & $102^{\circ} 10^{\prime}$ & 1500 & 370 \\
\hline 7 & MX94-107 & General Cepeda & Coahuila & Mexico & $-26^{\circ} 57^{\prime}$ & $102^{\circ} 05^{\prime}$ & 1400 & 371 \\
\hline 8 & MX94-115 & Peñon Blanco & Durango & Mexico & $-24^{\circ} 47^{\prime}$ & $104^{\circ} 02^{\prime}$ & 1700 & 469 \\
\hline 9 & MX94-026 & Ocampo & Coahuila & Mexico & $-27^{\circ} 19^{\prime}$ & $102^{\circ} 24^{\prime}$ & 1060 & 244 \\
\hline 10 & MX94-002 & San Juan de Sabinas & Coahuila & Mexico & $-27^{\circ} 51^{\prime}$ & $101^{\circ} 07^{\prime}$ & 339 & 488 \\
\hline 11 & MX94-328 & Bustamante & Nuevo Leon & Mexico & $-26^{\circ} 32^{\prime}$ & $100^{\circ} 30^{\prime}$ & 1600 & 527 \\
\hline 12 & MX94-053 & Villa Union & Coahuila & Mexico & $-28^{\circ} 15^{\prime}$ & $100^{\circ} 43^{\prime}$ & 380 & 592 \\
\hline 17 & MX94-326 & El Carmen & Nuevo Leon & Mexico & $-24^{\circ} 36^{\prime}$ & $100^{\circ} 29^{\prime}$ & 2015 & 408 \\
\hline 18 & MX94-334 & Nazas & Durango & Mexico & $-25^{\circ} 14^{\prime}$ & $104^{\circ} 08^{\prime}$ & 1300 & 349 \\
\hline 19 & MX94-239 & Saucillo & Chihuahua & Mexico & $-27^{\circ} 59^{\prime}$ & $105^{\circ} 17^{\prime}$ & 1286 & 333 \\
\hline
\end{tabular}

${ }^{\mathrm{z} S e e d l i n g s ~ w e r e ~ g r o w n ~ a t ~ a ~ c o m m o n ~ o r c h a r d ~ i n ~ S o m e r v i l l e, ~ T X . ~ E x c e p t ~ f o r ~ s e e d s t o c k s ~ 8, ~ 9, ~ 10, ~ 11, ~ 13, ~ a n d ~ 18, ~ f o r ~ w h i c h ~ o n l y ~ t w o ~ s e e d l i n g s ~ w e r e ~}$ available, three seedlings per seedstock were used for this research. 


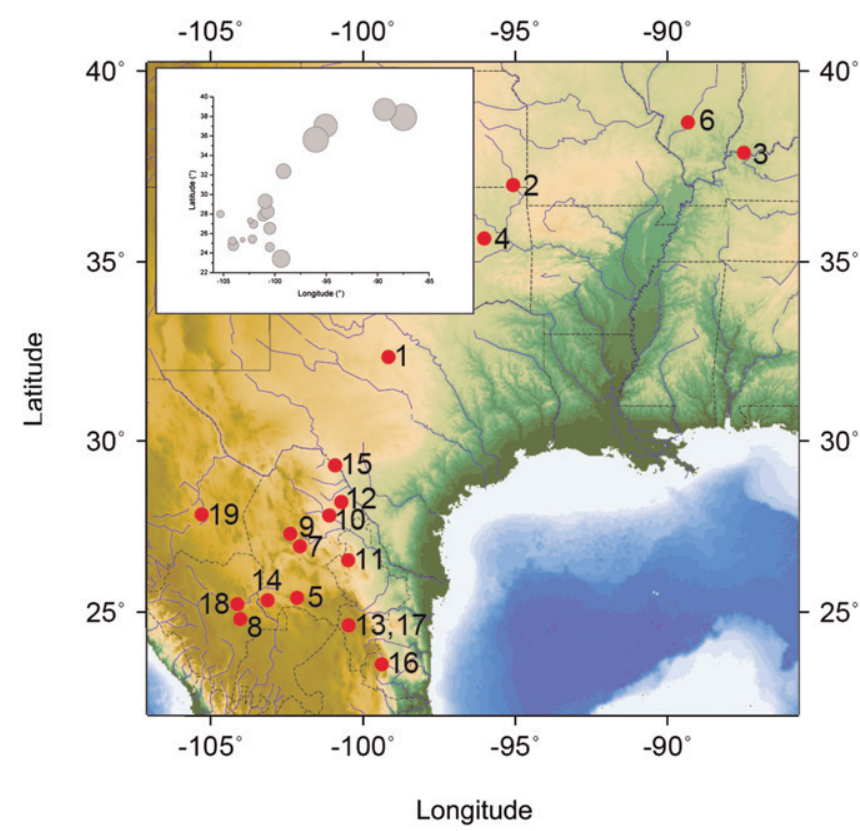

Fig. 1. Sites of origin for open-pollinated pecan seeds from the United States (seedstocks 1-4 and 6) and Mexico (seedstocks 5 and 7-19) used in the study. Seedlings were grown at a common orchard in Somerville, TX. Specific locations of each seedstock are indicated in Table 1. Inset: Historical annual precipitation data of sites of origin for open-pollinated pecan seeds used in the study. Size of circles is proportional to data reported in Table 1.

et al., 2007). Five counts were obtained from each cast by carefully numbering the veins to avoid counting the same area again. Each count was made between two adjacent veins and then the slide was moved to the next set of veins for the next count on the same leaf. Counts were made across samples by tree for each seed stock in each block. A single investigator made the SD and ED counts three times at different times during the duration of the experiment. The number of stomata and epidermal cells was used to calculate SD and ED. Stomatal index was calculated as $\mathrm{SI}=[\mathrm{SD} /(\mathrm{SD}+\mathrm{ED})] \times 100$. Total cell number (TC) was obtained by adding SD and ED.

${ }^{13}$ C Discrimination. Three 10 - to 15 -cm-long twigs per tree were collected from the previous season's shoots in Jan. 2007 from the north and south sides of the trees. The twigs were debudded, cut into 2 - to 3 -cm-long sections, dried at $70^{\circ} \mathrm{C}$ for $72 \mathrm{~h}$, and ground to pass through the 40-mesh screen on a Wiley mill (Glenn et al., 2003). Three samples per tree of $2 \pm 0.05 \mathrm{mg}$ were loaded into tin capsules and shipped to the Stable Isotope Facility at University of California, Davis, where they were analyzed for ${ }^{13} \mathrm{C}$ content. ${ }^{13} \mathrm{C}$ discrimination $(\Delta)$ was calculated using the formula $\Delta=\left(\delta_{\mathrm{a}}-\delta_{\mathrm{p}}\right) /\left(1-\delta_{\mathrm{p}}\right)$, where $\delta_{\mathrm{p}}$ is the isotopic composition of the plant material and $\delta_{\mathrm{a}}$ is that of air assumed to be $-8 \%(=-0.8 \%)$ (Farquhar et al., 1989).

Meteorological Data. The mean amount of precipitation received in each of the sites and the elevation of geographical locations for the United States and Mexico were obtained from the National Climatic Data Center (2010) and from the Meteorological National Service (Servicio Meteorològico Nacional, 2010) of Mexico, respectively.

STATISTICAL DESign AND ANALYSIS. The test was composed of three randomized complete blocks, each having one seedling from each of the 19 entries. Variability and seedstock differentiation were estimated by analysis of variance (ANOVA) and Student's $t$ test using SAS (Version 9.1; SAS Institute, Cary,
NC). ANOVA was structured to allow unequal replications for each seedstock resulting from occasionally missing trees. Differences $(P \leq 0.05)$ between means were determined by conservative $\mathrm{t}$ grouping for least squares means.

\section{Results}

A $t$ test conducted to test the difference between the leaf anatomical features (SD and ED) revealed that there were no differences between the north and south sides of the trees $[P=$ 0.60 (data not shown)] and, consequently, the data were pooled. Stomatal density was very consistent among seedlings of a common seedstock but differed as much as twofold between some seedstocks (Table 2). The greatest SD was recorded in seedstock 16 from Jaumave on the eastern coast of Mexico and the lowest in seedstock 19 from Saucillo on the western coast (Table 2). Epidermal cell density also differed greatly between seedstocks (Table 2) but was negatively correlated with stomatal density (Fig. 2). Stomatal index followed the same pattern as SD and was greatest and lowest in seedstocks from Jaumave and Saucillo, respectively (data not shown).

Variation in SD, SI, and $\Delta$ of pecan seedstocks from the United States along the latitudinal and longitudinal gradient indicated that neither latitude nor longitude had an effect (data not shown). However, variation of seedstocks from Mexico along the latitudinal and longitudinal gradient showed that longitude had a greater effect on the patterns of distribution of TC, SD, and ED (Fig. 3) than latitude (data not shown). Trees grown from seed originating from western Mexico had more cells and fewer stomata per unit leaf area than trees grown from

Table 2. Stomatal density (SD) and epidermal cell density (ED) of leaves of pecan seedlings grown from open-pollinated seeds from the United States (seedstocks 1-4 and 6) and Mexico (seedstocks 5 and $7-19){ }^{\mathrm{z}}$

\begin{tabular}{|c|c|c|}
\hline \multirow{2}{*}{$\begin{array}{l}\text { Seedstock } \\
\text { no. }\end{array}$} & $\mathrm{SD}$ (stomata $/ \mathrm{mm}^{2}$ & $\mathrm{ED}\left(\mathrm{cells} / \mathrm{mm}^{2}\right)$ \\
\hline & \multicolumn{2}{|c|}{ Mean \pm SE } \\
\hline 19 & $350 \pm 8 \mathrm{j}^{\mathrm{y}}$ & $2222 \pm 32 \mathrm{a}$ \\
\hline 18 & $406 \pm 9 \mathrm{i}$ & $2074 \pm 76 b$ \\
\hline 8 & $417 \pm 12 \mathrm{hi}$ & $2021 \pm 62 b$ \\
\hline 2 & $435 \pm 6$ ghi & $1689 \pm 68 c$ \\
\hline 14 & $437 \pm 9$ ghi & $1690 \pm 62 c$ \\
\hline 1 & $450 \pm 7 \mathrm{fgh}$ & $1698 \pm 60 c$ \\
\hline 9 & $460 \pm 10$ efg & $1566 \pm 76 \mathrm{de}$ \\
\hline 10 & $465 \pm 11$ efg & $1523 \pm 56$ ef \\
\hline 15 & $466 \pm 9$ efg & $1630 \pm 42 \mathrm{~cd}$ \\
\hline 3 & $467 \pm 10$ efg & $1692 \pm 36 \mathrm{c}$ \\
\hline 11 & $476 \pm 12 \mathrm{def}$ & $1509 \pm 76$ efg \\
\hline 17 & $484 \pm 9$ de & $1497 \pm 51$ efg \\
\hline 7 & $485 \pm 8 \mathrm{de}$ & $1354 \pm 55 \mathrm{~h}$ \\
\hline 6 & $491 \pm 9 \mathrm{de}$ & $1479 \pm 49 \mathrm{fg}$ \\
\hline 13 & $508 \pm 12 \mathrm{~d}$ & $1420 \pm 73 \mathrm{gh}$ \\
\hline 4 & $544 \pm 9 \mathrm{c}$ & $1245 \pm 63 \mathrm{i}$ \\
\hline 12 & $556 \pm 10 \mathrm{c}$ & $1188 \pm 36 \mathrm{i}$ \\
\hline 5 & $604 \pm 8 b$ & $1436 \pm 58 \mathrm{~g}$ \\
\hline 16 & $728 \pm 9 \mathrm{a}$ & $758 \pm 61 \mathrm{j}$ \\
\hline
\end{tabular}

${ }^{\mathrm{z}}$ Data were collected from five casts obtained from different leaves of each tree and five counts were obtained from each cast. Seedlings were grown at a common orchard in Somerville, TX.

${ }^{y}$ Means within same column indicated by different letters are significantly different at $P \leq 0.05$ by conservative t grouping for least squares means. 


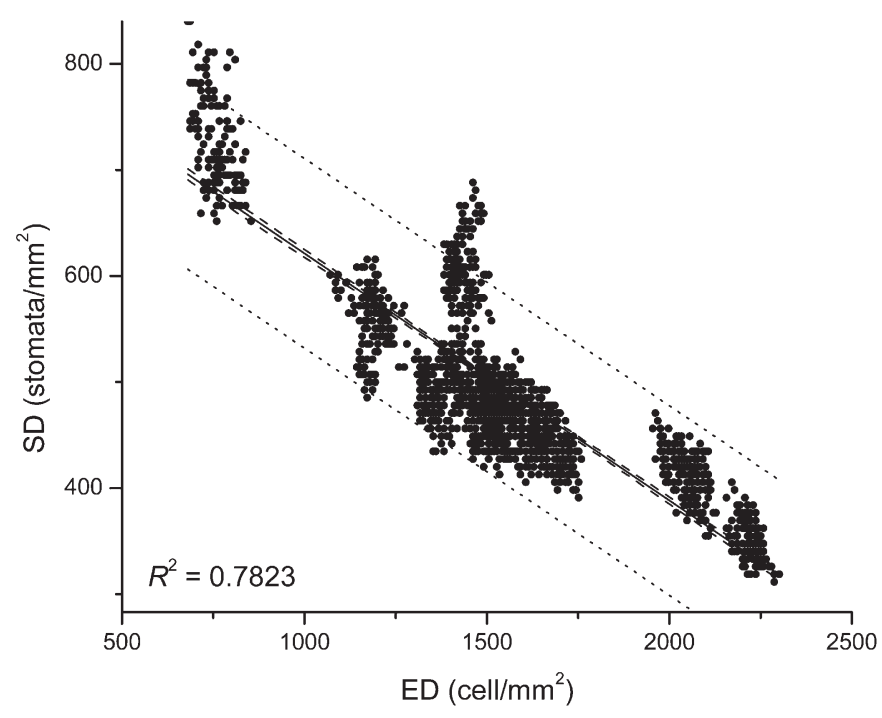

Fig. 2. Relationship between stomatal density (SD) and epidermal cell density (ED) of leaves of pecan seedlings grown from pecan seedstocks from Mexico grown in Somerville, TX. Dashed lines indicate upper and lower $95 \%$ confidence limits; dotted lined indicate upper and lower $95 \%$ prediction limits.
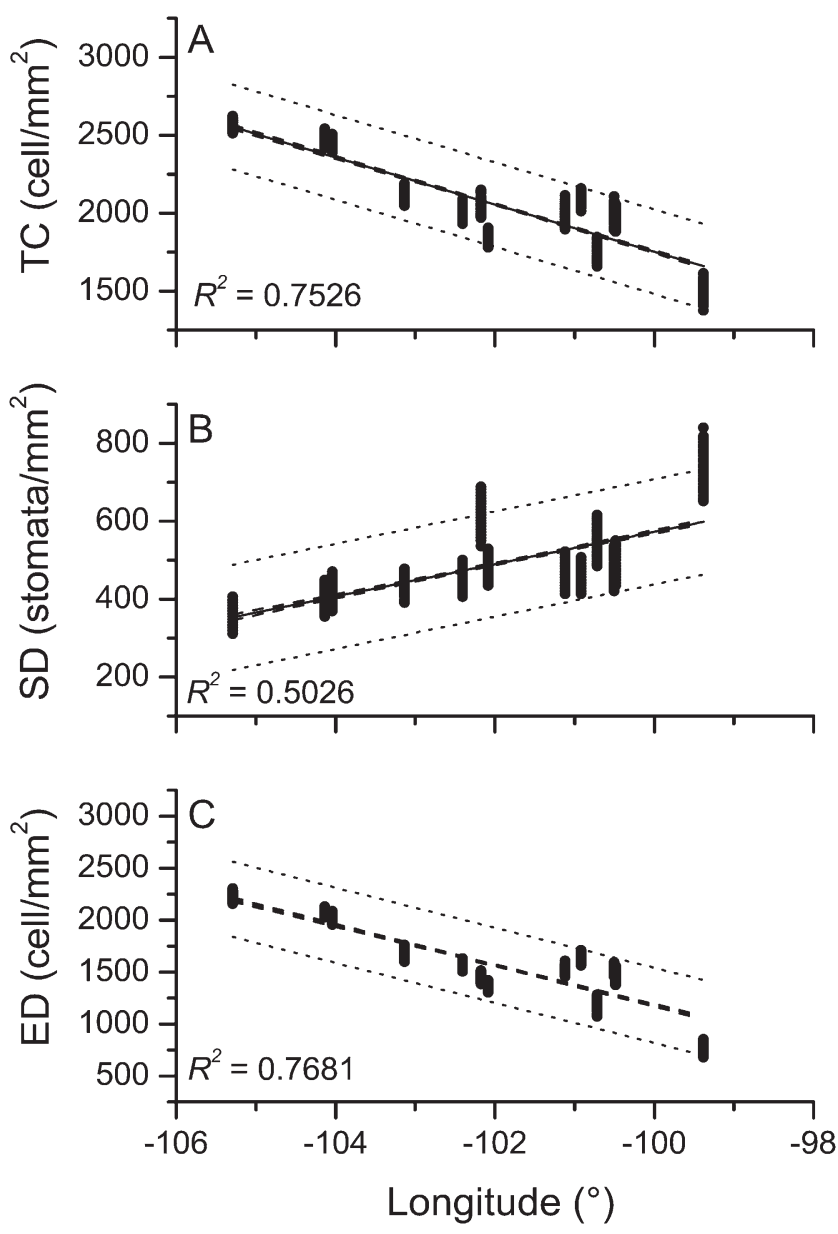

Fig. 3. Relationship between (A) total cell number (TC), (B) stomatal density (SD), and (C) epidermal cell density (ED) of leaves of pecan seedlings and the longitude of the seedstock site of origin. Seedlings were grown at a common orchard in Somerville, TX. Dashed lines indicate upper and lower 95\% confidence limits; dotted lined indicate upper and lower $95 \%$ prediction limits. seedstock originating in eastern Mexico (Fig. 3A-B) with a very strong relationship existing between TC and longitude (Fig. 3A). Stomatal density for Mexican seedstocks increased from 300 to 700 stomata $/ \mathrm{mm}^{2}$ as the longitude increased from $-105^{\circ}$ to $-100^{\circ}$ (Fig. 3B). On the other hand, as the longitude increased, ED for Mexican seedstocks decreased (Fig. 3C) and SI increased from 10 to 40 (data not shown).

A $t$ test conducted to test the difference between $\Delta$ on north and south sides of trees revealed that there were no differences $(P=0.80)$ and the data were pooled (Table 3$)$. Although there were no clear patterns for distribution of $\Delta$ along longitudinal and latitudinal gradients (data not shown), $\Delta$ tended to increase with decreasing mean annual precipitation $(P<0.001)$ (Fig. $4 A)$. Stomatal density showed a direct linear relationship with annual precipitation with lower SD associated with seedstocks collected from areas characterized by lower rainfall (Fig. 4B).

\section{Discussion}

Historical climate data indicates that in Mexico, annual precipitation decreases along the longitudinal gradient from the east to the west with greater precipitation east of longitude $-101^{\circ}$ (Table 1). Among the Mexican seedstock provenances investigated in this study, the greatest precipitation is reported in Jaumave, Tamaulipas, in the east (Table 1; Fig. 1). Elevation pattern in the United States and Mexico indicates an increase in the precipitation from the east to the west. The SD values for Mexican seedstocks showed a strong trend across the east-west gradient (Fig. 3), representing a possible adaptation to local differences in annual precipitation (Fig. 4). Seedstock from Jaumave on the east coast of Mexico had the greatest SD, whereas a seedstock from Saucillo on the west coast displayed

Table 3. Isotopic ${ }^{13} \mathrm{C}$ discrimination $(\Delta)$ of leaves of pecan seedlings grown from open-pollinated seeds from the United States (seedstocks 1-4 and 6) and Mexico (seedstocks 5 and 7-19). ${ }^{\mathrm{z}}$

\begin{tabular}{rl}
\hline Seedstock no. & ${ }^{13} \mathrm{C}$ discrimination $[\mathrm{mean} \pm \mathrm{SE}(\Delta)]$ \\
\hline 10 & $22.56 \pm 0.39 \mathrm{a}^{\mathrm{y}}$ \\
1 & $22.45 \pm 0.33 \mathrm{a}$ \\
5 & $22.21 \pm 0.33 \mathrm{ab}$ \\
18 & $22.10 \pm 0.39 \mathrm{abc}$ \\
14 & $22.10 \pm 0.33 \mathrm{abc}$ \\
2 & $22.04 \pm 0.33 \mathrm{abc}$ \\
13 & $21.86 \pm 0.39 \mathrm{abcd}$ \\
19 & $21.78 \pm 0.33 \mathrm{abcd}$ \\
9 & $21.74 \pm 0.39 \mathrm{abcd}$ \\
6 & $21.70 \pm 0.33 \mathrm{abcd}$ \\
11 & $21.68 \pm 0.39 \mathrm{abcd}$ \\
3 & $21.68 \pm 0.33 \mathrm{abcd}$ \\
12 & $21.68 \pm 0.33 \mathrm{abcd}$ \\
7 & $21.57 \pm 0.33 \mathrm{bcd}$ \\
8 & $21.38 \pm 0.39 \mathrm{bcd}$ \\
4 & $21.37 \pm 0.33 \mathrm{~cd}$ \\
15 & $21.28 \pm 0.33 \mathrm{~cd}$ \\
17 & $21.27 \pm 0.33 \mathrm{~cd}$ \\
16 & $21.11 \pm 0.33 \mathrm{~d}$
\end{tabular}

${ }^{\mathrm{z}}$ Seedlings were grown at a common orchard in Somerville, TX. Data are an average of three samples from the twigs on north and south sides of each tree.

${ }^{\mathrm{y}}$ Means within same column indicated by different letters are significantly different at $P \leq 0.05$ by conservative t grouping for least squares means. 

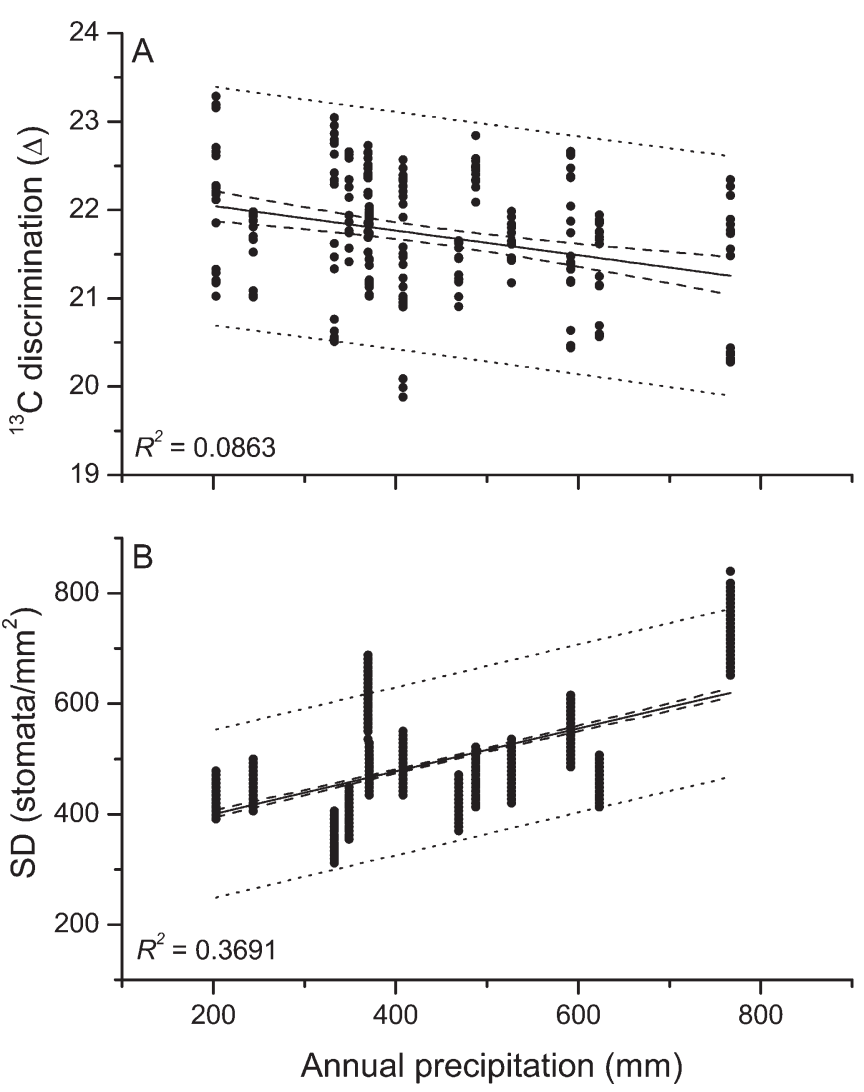

Fig. 4. Relationship between (A) ${ }^{13} \mathrm{C}$ discrimination and (B) stomatal density (SD) of leaves of pecan seedlings and the annual precipitation of the seedstock site of origin. Seedlings were grown at a common orchard in Somerville, TX. Dashed lines indicate upper and lower 95\% confidence limits; dotted lined indicate upper and lower $95 \%$ prediction limits

the least value. The trend presented here agrees with theories presented on optimal stomatal regulation by Cowan (1977) and Mäkelä et al. (1996), who proposed that aggressive water use strategies are associated with plants from wetter climates. In a study conducted on several species of Opuntia Mill. in Mexico, the greatest variation between the subspecies was reported for SD and SI (Conde, 1975). Similarly, SD and SI in the present study were the most variable among seedstocks, indicating that these traits could be of adaptive value to pecan.

The strong correlation between SD (and SI and ED) with longitude in the Mexican samples suggests that those trees may represent populations that have been present and isolated from each other long enough to develop local adaptations. Mexico may have been a refuge for pecans during the last glacial maximum based on molecular genetic analysis showing the greatest number of plastid haplotypes in Mexico with decreasing haplotype diversity going north (Grauke et al., 2010). Increased TC in western populations could result in increased leaf weight per area (leaf density), which is consistent with a previous study (Grauke et al., 2003).

Previous research (Sagaram et al., 2007) showed that 'Pawnee' pecan had intermediate SD between its two parents, implying that both parents influence the trait. The great consistency in SD in open-pollinated seedlings of a common maternal parent suggests that the pollen parents were consistent within a population and differed between populations.

Plants can avoid drought stress in several ways such as increasing WUE and limiting stomatal opening at low water potentials (Levitt, 1980). Consequently, plants with a higher WUE may need less water to produce the same amount of biomass as compared with plants with a lower WUE. The measurement of season-long integrated ${ }^{13} \mathrm{C}$ composition of a sample compared with a standard is also an indicator of the WUE of a plant (Farquhar et al., 1989). WUE is related to both environmental factors (Garten and Taylor, 1992) and genetic characteristics of the species (Zhang et al., 1993). Genetic variation in isotopic composition can be an important tool to understand the relationship and interaction between genotype and environment. If genotype performance is stable across multiple environments, then genotypic selection can be generalized for that particular trait (Cregg et al., 2000). Species with high WUE would have an adaptive benefit in situations wherein water availability is a constraint for plant growth (Ares et al., 2000). Plants with the $C_{3}$ pathway of photosynthesis reduce $\mathrm{CO}_{2}$ using the enzyme ribulose-1,5-bisphosphate carboxylase oxygenase (Rubisco). This enzyme discriminates against the heavier carbon isotope $\left({ }^{13} \mathrm{C}\right)$, resulting in relatively low levels of ${ }^{13} \mathrm{C}$ (Boutton, 1991). Carbon isotopic composition can be reported directly as composition $\left(\delta^{13} \mathrm{C}\right)$ or as discrimination $(\Delta)$. The advantage of reporting it as $\Delta$ is that it directly indicates the "consequences of biological processes," whereas $\delta^{13} \mathrm{C}$ is the outcome of both "source isotopic composition and carbon isotope discrimination" (Farquhar et al., 1989). The $\Delta$ values usually decrease as water becomes less available, indicating a downregulation of stomatal conductance and increase in WUE (Diefendorf et al., 2010). Consequently, $\Delta$ is a timeintegrated parameter to measure WUE. The relationship between $\Delta$ and WUE is inverse with high $\Delta$ values corresponding to low long-term WUE (Farquhar et al., 1989). When the $\Delta$ values found here are compared with the typical $\Delta$ values reported for $\mathrm{C}_{3}$ species $(15 \%$ to $28 \%$ ), it is clear that pecan displays average WUE. The data presented here, however, showed that $\Delta$ increases as annual rainfall precipitation decreases. According to Diefendorf et al. (2010), mean annual precipitation is the strongest predictor of leaf $\Delta$ among the environmental parameters investigated (precipitation, altitude, temperature, latitude). High correlation between the $\Delta$ values and mean rainfall of the warmest time of the year was found also for 22 Nothofagus Blume species (Read and Farquhar, 1991). Pecan stomata are insensitive to high temperatures and do not close under unfavorable temperature conditions (Andersen and Brodbeck, 1988). Perhaps this can be attributed to high photosynthetic rates and low WUE for the species among temperate fruit trees (Andersen and Brodbeck, 1988). The observed insensitivity of pecan stomata to high temperatures and light intensities also likely translates into the high seasonlong ${ }^{13} \mathrm{C}$ isotopic discrimination values $(21 \%$ to $23 \%)$ observed here. Moreover, pecan does not adjust stomatal aperture in response to intermittent cloud cover, thus behaving like a nonsolar-tracking species (Andersen, 1991), and this may result in higher transpiration rates and reduced WUE.

This study reiterated the earlier findings of low WUE for pecan (Lombardini et al., 2005) and showed that SD in the evaluated seedstocks was more directly correlated to annual precipitation than WUE. The number of stomata in seedstocks from drier environments on the western region of Mexico was lower from those on the eastern coast. This is likely an adaptation of the western seedstocks to drier environments. The present study evaluated pecan seedstocks from central Mexico but not from the southern part of the country. However, there is 
a possibility that greater adaptation to limiting water availability can be observed in seedstocks in southern Mexico as far as Oaxaca. Such an attempt at comparing leaf anatomical characteristics in different seedstocks from ecogeographic locations with more diverse environmental conditions would be more inclusive of the adaptation strategies for drought along a geographic context.

\section{Literature Cited}

Andersen, P.C. 1991. Photosynthetic characteristics of pecan and ten species of fruit crops with emphasis on sun tracking/non-sun tracking responses, p. 168-174. In: B.W. Wood and J.A. Payne (eds.). Pecan husbandry: Challenges and opportunities. U.S. Dept. Agr., Agr. Res. Serv. ARS-96.

Andersen, P.C. and B.V. Brodbeck. 1988. Net $\mathrm{CO}_{2}$ assimilation and plant water relations characteristics of pecan growth flushes. J. Amer. Soc. Hort. Sci. 113:444-450.

Ares, A., J.H. Fownes, and W. Sunday. 2000. Genetic differentiation of intrinsic water-use efficiency in the Hawaiian native Acacia koa. Intl. J. Plant Sci. 161:909-915.

Bhagwat, S.G. and C.R. Bhatia. 1993. Selection for flag leaf stomatal frequency in bread wheat. Plant Breed. 110:129-136.

Boutton, T.W. 1991. Stable carbon isotope ratios of natural materials: II. Atmospheric, terrestrial, marine, and freshwater environments, p. 173-185. In: D.C. Coleman and B. Fry (eds.). Carbon isotope techniques. Academic Press, San Diego, CA.

Conde, L.F. 1975. Anatomical comparisons of five species of Opuntia (Cactaceae). Ann. Mo. Bot. Gard. 62:425-473.

Cowan, I.R. 1977. Stomatal behaviour and the environment. Adv. Bot. Res. 4:117-227.

Cregg, B.M. 1993. Seed-source variation in water relations, gasexchange, and needle morphology of mature ponderosa pine trees. Can. J. For. Res. 23:749-755.

Cregg, B.M. 1994. Carbon allocation, gas exchange, and needle morphology of Pinus ponderosa genotypes known to differ in growth and survival under imposed drought. Tree Physiol. 14:883898.

Cregg, B.M., J. Miguel Olivas-Garcia, and T.C. Hennessey. 2000. Provenance variation in carbon isotope discrimination of mature ponderosa pin trees at two locations in the Great Plains. Can. J. For. Res. 30:428-439.

Diefendorf, A.F., K.E. Mueller, S.L. Wing, P.L. Koch, and K.H. Freeman. 2010. Global patterns in leaf ${ }^{13} \mathrm{C}$ discrimination and implications for studies of past and future climate. Proc. Natl. Acad. Sci. USA 107:5738-5743.

Farquhar, G.D., J.R. Ehleringer, and K.T. Hubick. 1989. Carbon isotope discrimination and photosynthesis. Annu. Rev. Plant Physiol. Mol. Biol. 40:503-537.

Fisher, D.G. 1985. Morphology and anatomy of the leaf of Coleus blumei (Lamiaceae). Amer. J. Bot. 72:392-406.

Garten C.T., Jr. and G.E. Taylor, Jr. 1992. Foliar $\delta^{13} \mathrm{C}$ within a temperate deciduous forest: Spatial, temporal, and species sources of variation. Oecologia 90:1-7.

Glenn, D.M., A. Erez, G.J. Puterka, and P. Gundrum. 2003. Particle films affect carbon assimilation and yield in 'Empire' apple. J. Amer. Soc. Hort. Sci. 128:356-362.

Grauke, L.J. 1982. The influence of zinc carriers on the foliar absorption of zinc by pecan and corn. PhD diss., Texas A\&M Univ., College Station, TX.

Grauke, L.J., M.A. Mendoza-Herrera, and M.L. Binzel. 2010. Plastid microsatellite markers in Carya. Acta Hort. 859:237-246.

Grauke, L.J., J.B. Storey, and E.R. Emino. 1987. Influence of leaf age on the upper and lower leaf surface features of juvenile and adult pecan leaves. J. Amer. Soc. Hort. Sci. 112:835-841.

Grauke, L.J., B.W. Wood, T.E. Thompson, and J.B. Storey. 2003. Leaf structure and nutrient content vary in native pecan populations. Proc. Texas Pecan Growers Assn. 70:59-60.
Hardin, J.W. and D.E. Stone. 1984. Atlas of foliar surface features in woody plants. VI. Carya (Juglandaceae) of North America. Brittonia 36:140-153.

Heursel, J., R. Ceulemans, and N. Ibrahim. 1987. Stomatal density and length for breeding of evergreen azaleas (Rhododendron simsii Planch.). Plant Breed. 99:340-343.

Jarvis, A.J. and W.J. Davies. 1998. The coupled response of stomatal conductance to photosynthesis and transpiration. J. Expt. Bot. 49: 399-406.

Jones, H.G. 1998. Stomatal control of photosynthesis and transpiration. J. Expt. Bot. 49:387-398.

Jurena, M.R. 2005. Soil survey of Burleson County. Official soil series descriptions. 12 Dec. 2010. <http://soildatamart.nrcs.usda.gov/ Manuscripts/TX051/0/maps/Tables.pdf $>$.

Kleinhenz, M.D., J.B. Bamberg, and J.P. Palta. 1995. Use of stomatal index as a marker to screen backcross populations of two wild potato species segregating for freezing tolerance. Amer. Potato J. 72:243-250.

Levitt, J. 1980. Responses of plants to environmental stresses. Vol. II. Water, radiation, salt, and other stresses. Academic Press, New York, NY.

Li, C.Y. 2000. Population differences in water-use efficiency of Eucalyptus microtheca seedlings under different watering regimes. Physiol. Plant. 108:134-139.

Lombardini, L., M.K. Harris, and D.M. Glenn. 2005. Effects of particle film application on leaf gas exchange, water relations, nut yield, and insect populations in mature pecan trees. HortScience 40:1376-1380.

Mäkelä, A., F. Berninger, and P. Hari. 1996. Optimal control of gas exchange during drought: Theoretical analysis. Ann. Bot. (Lond.) 77: 461-467.

Masle, J., S.R. Gilmore, and G.D. Farquhar. 2005. The ERECTA gene regulates plant transpiration efficiency in Arabidopsis. Nature 436: 866-870.

Nagel, K. 1914. Studien über die familie der Juglandaceen. Bot. Jahrb. Syst. Pflanzengesch. Pflanzengeogr. 50:459-530.

National Climatic Data Center. 2010. Climate data inventories. 10 Dec. 2010. <http://www.ncdc.noaa.gov/oa/ncdc.html>.

Nayeem, K.A. 1989. Genetic and environmental variation in stomatal frequency and distribution in wheat Triticum spp. Cereal Res. Commun. 17:51-57.

Nemati, A. and C.R. Roberts. 1968. Some structural differences in the leaves of six pecan cultivars and the possible significance to production. Ann. Rpt. Northern Nut Growers Assn. 59:96-99.

Parmentier, P. 1911. Recherches anatomiques et taxonomiques sur les Juglandacées. Revue Géneìrale de Botanique 23:341-364.

Read, J. and G. Farquhar. 1991. Comparative studies in Nothofagus (Fagaceae). I. Leaf carbon isotope discrimination. Funct. Ecol. 5: 684-695.

Sagaram, M., L. Lombardini, and L.J. Grauke. 2007. Variation in leaf anatomy of pecan cultivars from three ecogeographic locations. J. Amer. Soc. Hort. Sci. 132:592-596.

Servicio Meteorològico Nacional. 2010. Temperatura y precipitación. 10 Dec. 2010. <http://smn.cna.gob.mx/climatologia/climatologia.html>.

Thompson, T.E. and L.J. Grauke. 1991. Pecans and other hickories (Carya). Acta Hort. 290:839-904.

Van Rensburg, L., J. Peacock, and G.H.J. Krueger. 1999. Boundary layer, stomatal geometry and spacing, in relation to drought tolerance in four Nicotiana tabacum L. cultivars. South African J. Plant Soil 16:44-49.

Wilson, D. 1971. Selection responses of stomatal length and frequency, epidermal ridging, and other leaf characteristics in Lolium perenne L. 'Grasslands Ruanui'. N. Z. J. Agr. Res. 14:761-771.

Wood, B.W., L.J. Grauke, and J.A. Payne. 1998. Provenance variation in pecan. J. Amer. Soc. Hort. Sci. 123:1023-1028.

Yamashita, H., H. Satoh, T. Omura, T. Takita, and H. Nishiyama. 1995. Difference in stomatal frequency in leaves of mutant lines and its inheritance in rice. Breed. Sci. 45:105-106.

Zhang, J.W., J.D. Marshall, and B.C. Jaquish. 1993. Genetic differentiation in carbon isotope discrimination and gas exchange in Pseudotsuga menziesii. Oecologia 93:80-87. 